\title{
Arachidonic acid as an elicitor of the plant defense response to phytopathogens
}

\author{
Emiliya G Dedyukhina ${ }^{1 *}$, Svetlana V Kamzolova ${ }^{2+}$ and Mikhail B Vainshtein ${ }^{1,3+}$
}

\begin{abstract}
Review summarizes both literature and own experimental data on the application of arachidonic acid (AA, $C_{20: 4}$ omega-6) as an elicitor of the plant defense reactions to phytopathogens. The elicitation activity of AA was shown to depend considerably on its concentration. High AA concentrations (over $10^{-5} \mathrm{M}$ ) induce necrosis of plant tissues and accumulation of antimicrobial compounds (phytoalexins), whereas low AA concentrations $\left(10^{-7}-10^{-7} \mathrm{M}\right)$ elicit systemic and prolonged resistance to the phytopathogen infections that is similar to immunization process.

Biochemical mechanisms responsible for the elicitor activity of AA involve the whole complex of reactions including reconstruction of the cell ultrastructure, an increase in the amounts of certain enzymes and protective substances, a decrease in sterol content, redirection of isoprenoid biosynthesis from sterol derivatives toward sesquiterpenoid phytoalexins, and appearance of signal molecules, which are spread all over the plant tissues making them immunized. Field experiments revealed that the treatment of potato, tomato, sugar beet, and vine plants with low concentrations of pure AA or AA-containing preparations isolated from Phytophtora and Mortierella fungi increased plant resistance to diseases (late blight, common scrab, rhizoctonoise, cercosporose, powdery mildew, etc.) and thus enhanced the harvest yield. The application of AA-containing preparations is an alternative to the use of environmentally dangerous chemical fungicides. The processes of microbiological AA production from renewable inexpensive raw substrates are considered.
\end{abstract}

\section{Introduction}

Arachidonic acid (AA; 5,8,11,14-cis-eicosatetraenoic acid) belongs to omega- 6 group of essential polyunsaturated fatty acids, which cannot be synthesized by animals and humans and, thus, should be added to their diet. AA is involved in modulating of membrane fluidity and in various metabolic processes in human organism playing an important role as a direct precursor of physiologically active prostaglandins (series 2), leukotrienes, and a number of eicosanoids. Detailed information on the AA applications as a component of infant formula, dietary supplement, and precursor of pharmaceutical preparations is given in reviews [1-3]. The use of AA in agriculture as an elicitor of the plant defense reactions against phytopathogens is an extremely promising approach. This novel environmentally friendly method of plant defense is based on

\footnotetext{
* Correspondence: dedeg@rambler.ru

${ }^{\dagger}$ Equal contributors

'Laboratory of Physiology of Microorganisms, Institute of Biochemistry and Physiology of Microorganisms, Russian Academy of Sciences, Pushchino, Russia

Full list of author information is available at the end of the article
}

inducing natural, systemic, and prolonged plant resistance to diseases by application of biogenic elicitors in low concentrations. However, until now, it has not been widely applied.

Review is aimed at summarizing literature data on the application of AA-containing preparations for plant immunization against phytopathogens and on biochemical mechanisms responsible for the AA elicitor activity. Microbiological AA production is described shortly since these processes have been comprehensively considered in many reviews [1-4]; emphasis is placed on the use of low-cost waste substrates for AA synthesis.

\section{Review}

Microbiological production of arachidonic acid

Natural sources of AA include animal liver, adrenal glands, and egg yolk; however, AA content of these products is so low that they cannot satisfy increased requirements in this acid. As a rule, AA is absent in higher plants; the most active AA-producers were revealed among fungi belonging to the genus Mortierella (class Phycomycetes) [2-5]. It has been stated that fungi Mortierella alpina are 
the most attractive producers of AA (up to $70 \%$ of lipid); moreover, they are non-pathogenic and do not form mycotoxins and potentially allergenic spores under fermentation conditions [6]. It was found that AA-enriched lipids derived from $M$. alpina showed no mutagenic or clastogenic activity as well as the acute oral toxicity [7].

Thus, a limited supply of natural AA sources dictated necessity to develop microbiological AA production. At present, fermentation processes for AA synthesis with the use of Mortierella fungi are claimed with patents in Europe, China, Japan, and United States [1,8-10]. In the industrial AA production, carbohydrates are usually used as carbon substrates. However, high production cost of the AA-containing microbial lipids determined increased interest in the application of novel inexpensive and renewable carbon substrates. In recent years, glycerol and especially raw glycerol, which is formed in large amounts as a by-product of biodiesel production, had been considered as promising substrates for microbiological processes [11-16]. A current price of biodiesel-derived glycerol ranges from US $\$ 0.06$ to $\$ 0.11$ per pound that indicates the potentiality of its application for microbiological processes [17]. It was shown that Mortierella fungi were able to produce AA from pure glycerol $[18,19]$. Recently, the AA synthesis $(15 \%-20 \%$ of lipid) from glycerolcontaining biodiesel-derived wastes had been demonstrated with the use of selected M. alpina strains [20].

In order to reduce the cost of microbial oil, renewable inexpensive raw materials, such as lignocellulosic residues (rice hull hydrolysate), olive mill wastewater, and sweet sorghum extract, had been successfully applied for production of fungal lipids [21-25]. The semisolid fermentation process had been developed for oil production by oleaginous fungi from agro-industrial residues; this process provided for higher lipid accumulation compared to liquid cultures or solid-state fermentation and gave oil of high quality [21]. A mathematical model had been proposed which was able to predict biomass growth, lipid production, and substrate consumption under semisolid-state fermentation process [23]. Thus, it can be expected that the application of inexpensive substrates depreciates the cost of microbiological AA production and promotes extensive AA application in agriculture as an alternative to environmentally dangerous chemical fungicides.

\section{Mechanisms responsible for the elicitation activity of arachidonic acid}

At present, the term 'elicitors' designates metabolites of phytopathogens, which evoke a complex of defense reactions in plants [26]. A number of substances (proteins, glycoproteins, oligosaccharides, glucans, and polyunsaturated fatty acids) are known to exhibit elicitor activity [26-28]. The lipoglycoprotein (LGP) complex isolated from the late blight pathogen Phytophthora infestans was found to exhibit high elicitation activity due to the presence of AA and eicosapentaenoic acid (EPA) [29,30]. It has been suggested that AA is incorporated into certain membrane lipids and shows effect on activity of membrane proteins, which are subsequently involved in the hypersensitive response of plant cells [31,32]. The defense reactions induced by elicitors in plants can include [26]: (1) reparation of mechanically wounded plant tissues; (2) synthesis of antibiotics (phytoalexins); (3) accumulation of protease inhibitors; (4) generation of active forms of oxygen.

Detailed studies carried out in the Bach Institute of Biochemistry, Russian Academy of Sciences, (Moscow, Russian Federation) showed that the elicitor activity of AA-containing preparation (LGP complex) depends considerably on its concentration $[29,30,33]$. High concentrations of the AA preparation (5 $10^{-5} \mathrm{M}$ and higher) induced necrosis of potato tissues and synthesis of phytoalexins (PA), which were accumulated in necrotizing tissues in toxic for pathogen concentrations showing defense effect on plant. However, accumulated PA had been subsequently degraded by plant enzymes. Moreover, it was shown that PA-containing necrotizing cells were detached from healthy cells in the course of the hypersensitive reactions [34]. Therefore, after a week, plant tissues contained no PA and became again sensitive to phytopathogens. Thus, the defense effect of high elicitor concentrations was local and short-term.

When potato tubers were treated with low concentrations of AA preparation (from $10^{-7}$ to $10^{-8} \mathrm{M}$ ), no necrosis or PA were formed, but tissues acquired the capability for rapid mobilization of the whole complex of protective reactions in response to the subsequent contact with the late blight pathogen, $P$. infestans. This type of resistance was named 'induced resistance' or 'immunization' $[29,30]$. It was found that all tissues of potato tubers treated with AA preparation $\left(10^{-7} \mathrm{M}\right)$ became resistant to the $P$. infestans infection within a week after their treatment and retained this property for $2-3$ months. These results indicated that potato resistance to disease, which was elicited by low concentrations of AA, was prolonged and systemic $[29,30]$.

It was assumed that immunization of the elicitor-treated potato tubers proceeded through several stages [29]:

(1) Period from the plant treatment with elicitor to the development of systemic signal of immunization.

(2) Signal distribution through the potato tissues. It was found that increased resistance to $P$. infestans was developed in the surface layers of potato tubers on the second day after their treatment with low concentration $\left(10^{-7} \mathrm{M}\right)$ of elicitor (LGP complex) After a week, all potato tissues became resistant to the phytopathogen [29]. 
(3) Period of reorganization of metabolism and structure of potato tissues (usually from 48 to $96 \mathrm{~h}$ ), which includes considerable changes in cell ultrastructure, an increase in the amounts of enzymes and protective substances, and a decrease in sterol content. Electron-microscopic examinations revealed considerable changes in ultrastructure of AA-treated potato tissues: an increase both in the volume of agranular reticulum and in the number of mitochondria [29]. It was shown that potato tubers immunized with AA were characterized by increased activities of peroxidase and lipoxygenase [28,29]. It has been proposed that 5 -lipoxygenase was involved in the signal-response coupling to the AA elicitation of the hypersensitive response [35].

(4) Period of plant immunization, which can continue from several weeks to several months and even up to year.

(5) Lowering of immunization level when the tissue structures and biochemical characteristics return to normal state. This period can continue for several weeks. It is important that resistance to disease can be restored by secondary plant treatment with elicitor.

It is known that sterols play important role in the interactions of $P$. infestans with potato tissues, since the fungus exhibits auxotrophic requirements for sterols and fill up sterol deficiency at the expense of the host tissues [29]. It was found that sterol concentration in AAimmunized potato was decreased more than twofold, retained at this level for 2-3 months and then gradually returned to normal value. Thus, sterol deficiency in the AA-immunized potato tissues can be one of the defense reactions to infection caused by $P$. infestans [29]. A rapid redirection of isoprenoid biosynthesis from sterol derivatives toward sesquiterpenoid phytoalexins was found in plants of the Solanaceae family when wounded tissues were exposed to elicitors or fungal pathogens which induced a hypersensitive response [36,37].

At present, it is considered that initial mechanisms of phytoimmunity include formation of active forms of oxygen (superoxide and hydroxyl free radicals). These compounds are toxic for pathogens; moreover, they are involved in the plant signal systems. It was shown that AA $\left(10^{-8} \mathrm{M}\right)$ induced formation of superoxide radicals, which inhibited growth of P. infestans [26].

Experimental data unambiguously indicate the existence of intercellular signals in immunized cells, which are spread all over the tissues making them immunized $[29,33]$. It has been proposed that eicosapolyenoic acids, which are released upon the plant infection by oomycete pathogens, have transorganismal signaling activity. Experiments were carried out with transgenic Arabidopsis thaliana plants, which were capable of producing $C_{20: 2}$, $\mathrm{C}_{20: 3}$, and $\mathrm{C}_{20: 4}$ acids $[38,39]$. The resistance of transgenic plants to a wide range of biotic impacts (fungal or bacterial pathogens and an insect pest) together with the data obtained from experiments with individual fatty acids indicate that AA in plants, just as in animal systems, can function as a signaling molecule that not only triggers fatty acid-mediated defense responses but also elicits general stress signaling networks [39]. It is known that a number of compounds can fulfill a role of signaling molecules, such as jasmonic acid (derivative of linolenic acid), polypeptide systemin, oligosaccharides, etc. $[29,39,40]$. It was found that combined application of AA and jasmonic acid increased elicitor effect of AA on potato defense to $P$. infestans [40].

To conclude, it can be stated that low AA concentrations elicit development of the whole complex of systemic and prolonged defense reactions in plant tissues in response to phytopathogen infections that is similar to plant immunization.

\section{Practical application of arachidonic acid for defense of agricultural plants against phytopathogens}

The effect of LGP complex isolated from $P$. infestans, which contained AA and EPA, on defense of different varieties of potato and tomato against fungal and bacterial pathogens was studied in the Bach Institute of Biochemistry, Russian Academy of Sciences, (Moscow, Russian Federation) for 14 years (1977-1990) [30]. It was found that induced resistance of vegetative plants

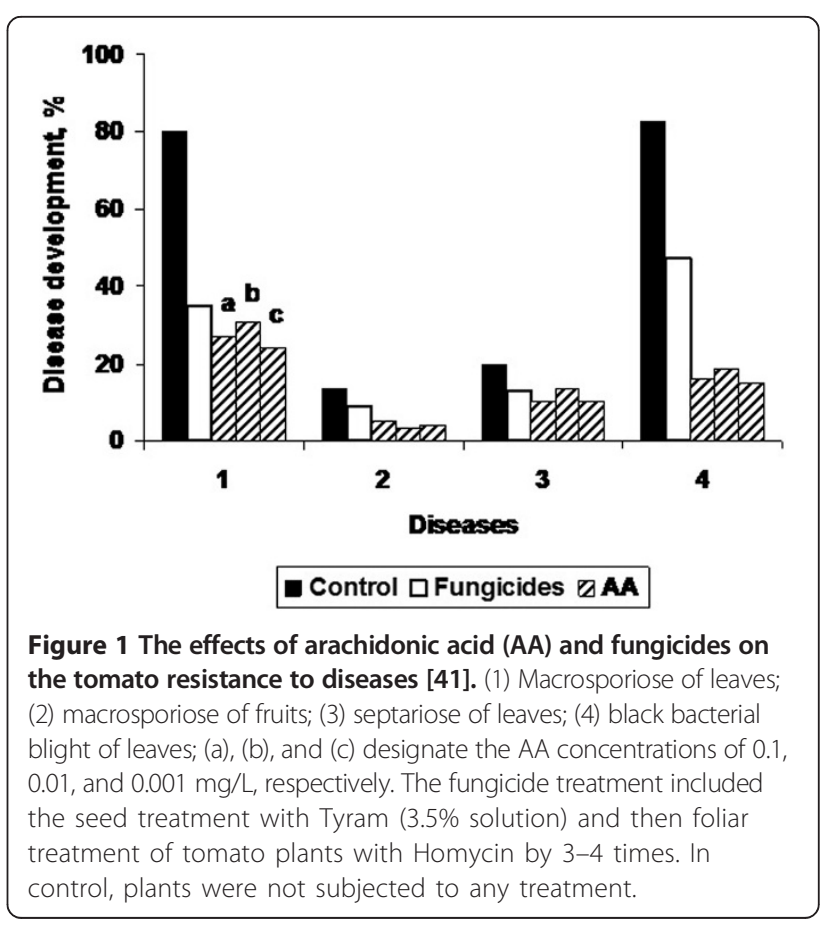




$\begin{aligned} & \text { Table } \mathbf{1} \text { The effect of the arachidonic acid-containing } \\
& \text { preparation on the plant resistance to diseases [42] }\end{aligned}$
\begin{tabular}{lllll}
\hline Disease & Plant & \multicolumn{3}{c}{ Disease development,\% } \\
\cline { 3 - 5 } & & Control & AA preparation & $\begin{array}{l}\text { Fungicide } \\
\text { (polycarbacine) }\end{array}$ \\
\hline Late blight & Potato & 22.3 & 6.8 & 5.6 \\
Common scrab & Potato & 29.5 & 12.6 & 16.8 \\
Rhizoctonoise & Potato & 21.7 & 10.1 & 19.4 \\
Cercosporose & Sugar & 36.9 & 19.8 & n.d. \\
& beet & & & \\
Powdery mildew & Grapes & 91.0 & 54.0 & n.d. \\
\hline
\end{tabular}

Note: In control, plants were not subjected to any treatment; 'n.d.' stands for 'not determined'.

and potato tubers was developed not only to $P$. infestans but also to Macrosporium solani, Alternaria solani, Rhizoctonia solani, Actinomyces scabes, and Pectobacterium phytophthorum. Tomato plants and fruits acquired resistance to P. infestans, A. solani, M. solani, Septoria lycopersici, Xanthomonas vesicatoria, and Meloidogyne incognita. Yield of the elicitor-treated potato tubers and tomato was increased by $10 \%-40 \%$ [30].

Comparative studies of the protective effects of LGP complex and individual AA and EPA on tomato plants showed that AA exhibited the highest elicitor activity [41]. The presowing treatment of tomato seeds was performed with low AA concentrations (0.001, 0.01, and $0.1 \mathrm{mg} / \mathrm{L}$ ) for $24 \mathrm{~h}$. To compare, seeds were treated with fungicide Tyram (3.5\% solution) and then foliar treatment of tomato plants was performed with fungicide Homycin by 3-4 times. In control experiments, no treatment of tomato seeds or plants was performed. Tomato plants were grown in open ground; experiments were repeated for three years. It was found that the treatment of tomato with AA and fungicides decreased development of the following diseases (as compared with control): macrosporiose of leaves (by 2.63.3 and 2.3 times, respectively), septariose of leaves (by 1.4-1.9 and 1.5 times, respectively), and black bacterial blight of leaves (by $4.4-5.5$ and 1.7 times, respectively). The results are summarized in Figure 1. Tomato yield under the AA and fungicide treatments increased up to $112 \%$ and $135 \%$, respectively, as compared with that in control [41].

In our experiments, a mixture of the fatty acid ethyl esters (FAEE) containing 30\% of AA was isolated from Mortierella hygrophila and applied for a foliar treatment of plants [42]. The application of fatty acids in the form of ethyl esters was performed to facilitate their penetration into plant tissues through a waxy cover of the leaves. The lipid preparation consisted of the mixture of FAEE, butylated hydroxytoluene (BHT, 1\% solution in $n$-hexane) as an antioxidant, and Tween 20 . The optimal concentrations of the preparation $\left(0.3\right.$ to $0.5 \mathrm{mg} / 100 \mathrm{~m}^{2}$ of sown area) were chosen in preliminary greenhouse experiments. Field experiments were carried out under naturally infected background.

Field experiments carried out at a sown area of 3 ha (Russian Potato Concern) revealed that a double foliar treatment of potato with the FAEE preparation in period of shoot growth and in the budding-early florescence phase decreased development of late blight, common scrab, and rhizoctonoise of potato tubers as compared to the control (untreated potato) on the average by $70 \%$, $35 \%$, and $54 \%$, respectively. The results are summarized in Table 1. The efficiency of double treatment of plants with the preparation was comparable with or even higher than that of thrice treatment with fungicide (polycarbacine) (Table 1). A foliar treatment of potato with the preparation increased the tuber yield by $11 \%-$ $12 \%$ in comparison with that obtained after treatment with the fungicide [42].

The studies carried out at a sown area of 2 ha (AllRussian Research Institute of Biological Plant Protection) showed that a single treatment of sugar beet plants (at the phase of 3 to 5 pairs of true leaves) with the FAEE preparation almost halved the development of cercosporose in comparison with that in control (Table 1). A single foliar treatment of sugar beet (at the phase of 5 to 6 pairs of true leaves) with the preparation at a sown area of 400 ha (All-Russian Research Institute of Sugar Beet and Sugar) resulted in an increase in the harvest yield by $11 \%-14 \%$ comparing with that without treatment [42].

The effect of the FAEE preparation on the resistance of vine plants to phytopathogens was tested at the North Caucasus Zonal Research Institute of Gardening and Vine-Growing (Krasnodar, Russian Federation). The vine plants at a sown area of 1 ha were sprayed once with the preparation in the buddingflorescence phase. The development of powdery mildew of grapes was reduced to 54\% comparing with 91\% in control (untreated plants) (Table 1). At the same time, the preparation showed no effect on the development of gray rot. On the whole, the yield of grapes increased by 1.5 times in comparison with that in control (without treatment) [42].

Thus, the results available in the literature demonstrate that the treatment of various agricultural plants with low concentrations of AA-containing preparations isolated from Phytophthora and Mortierella fungi increased the plant resistance to phytopathogens. Taking into account that microbial AA preparations are environmentally friendly, their employment makes it possible to reduce or even replace the application of dangerous fungicides, which pollute and destabilize ecosystems and endanger people health. 


\section{Conclusions}

Numerous experimental data indicate that application of AA and AA-containing microbial preparations as elicitors of plant defense reactions to the phytopathogen infections is a very promising alternative to the use of environmentally dangerous chemical fungicides. However, it should be taken into consideration that practical use of elicitors should satisfy certain conditions [43]: (1) it is very important to use proper concentrations of elicitors, since high concentrations of preparation can lead to formation of necrosis and synthesis of toxic phytoalexins that is accompanied by increased energy expenditure and plant weakening; (2) optimal doses of elicitors depend on plant variety and vegetation phase; (3) the elicitor efficiency is decreased under fast development of infections (epiphytotic); in this case, repeated elicitor treatment is necessary. Therefore, preliminary experiments should be carried out to select the optimal AA concentrations for the treatment of concrete plant species.

\section{Abbreviations \\ AA: arachidonic acid; PA: phytoalexins; LGP: lipoglycoprotein; EPA: eicosapentaenoic acid; BHT: butylated hydroxytoluene; FAEE: fatty acid ethyl esters.}

\section{Competing interests}

The authors declare that they have no competing interests.

\section{Authors' contributions}

EGD was involved in the manuscript drafting and made final approval of the version to be published. SVK made substantial contributions to acquisition, analysis, and interpretation of data and helped to draft the manuscript. MBV made substantive intellectual contributions to the manuscript drafting and revising it critically for important intellectual content. All authors read and approved the final manuscript.

\section{Author details \\ ${ }^{1}$ Laboratory of Physiology of Microorganisms, Institute of Biochemistry and Physiology of Microorganisms, Russian Academy of Sciences, Pushchino, Russia. 'Laboratory of Aerobic Metabolism of Microorganisms, Institute of Biochemistry and Physiology of Microorganisms, Russian Academy of Sciences, Pushchino, Russia. ${ }^{3}$ Pushchino State Institute of Natural Sciences, Moscow, Russia.}

Received: 5 August 2014 Accepted: 29 September 2014 Published online: 10 October 2014

\section{References}

1. Ratledge C (2004) Fatty acid biosynthesis in microorganisms being used for cell single oil production. Biochimie 86:807-815

2. Ward O, Singh A (2005) Omega-3/6 fatty acids: Alternative sources of production. Process Biochem 40:3627-3652

3. Dyal D, Narine SS (2005) Implications for the use of Mortierella fungi in the industrial production of essential fatty acids. Food Res Int 38:445-467

4. Dedyukhina EG, Chistyakova TI, Vainshtein MB (2011) Biosynthesis of arachidonic acid by Micromycetes (Review). Appl Biochem Microbiol (English translation from Prikl Biokhim Mikrobiol) 47:109-117

5. Eroshin VK, Satroutdinov AD, Dedyukhina EG, Chistyakova TI (2000) Arachidonic acid production by Mortierella alpina with growth-coupled lipid synthesis. Process Biochem 35:1171-1175

6. Streekstra H (1997) On the safety of Mortierella alpina for the production of food ingredients, such as arachidonic acid. J Biotechnol 56:153-165

7. Hempenius RA, Van Delft JM, Prinsen M, Lina BA (1997) Preliminary safety assessment of an arachidonic acid-enriched oil derived from Mortierella alpina: summary of toxicological data. Food Chem Technol 35:573-581
8. Akimoto K, Higashiyama K, Shimizu A (2000) Production of arachidonic acidcontaining lipid and dihomo-gamma-linolenic acid-containing lipid. Patent 2000069987

9. Barclay WR (2007) Method for production of arachidonic acid. US Patent Application 2007002050

10. Streekstra H, Brocken PJM (2009) Preparation of microbial oil. US Patent 2009003342

11. Papanikolaou S, Fakas S, Fick M, Chevalot I, Galiotou-Panayotou M, Komaitis M, Marc I, Aggelis G (2008) Biotechnological valorization of raw glycerol discharged after bio-diesel (fatty acid methyl esters) manufacturing process: Production of 1,3-propandiol, citric acid and single cell oil. Biomass Bioenergy 32:60-71

12. Rymowicz W, Fatykhova AR, Kamzolova SV, Rywińska A, Morgunov IG (2010) Citric acid production from glycerol-containing waste of biodiesel industry by Yarrowia lipolytica in batch, repeated batch, and cell recycle regimes. Appl Microbiol Biotechnol 87:971-979

13. Kamzolova SV, Fatykhova AR, Dedyukhina EG, Anastassiadis SG, Golovchenko NP, Morgunov IG (2011) Citric acid production by yeast grown on glycerol-containing waste from biodiesel industry. Food Technol Biotechnol 49:65-74

14. Chatzifragkou A, Makri A, Belka A, Bellou S, Mavrou M, Mastoridou M, Mystrioti P, Onjaro G, Aggelis G, Papanikolaou S (2011) Biotechnological conversion of biodiesel derived waste glycerol by yeast and fungal species. Energy 36:1097-1108

15. Morgunov IG, Kamzolova SV, Lunina JN (2013) The citric acid production from raw glycerol by Yarrowia lipolytica yeast and its regulation. Appl Microbiol Biotechnol 97:7387-7397

16. Bellou S, Moustogianni A, Makri A, Aggelus G (2012) Lipids containing polyunsaturated fatty acids synthesized by Zygomycetes grown on glycerol. Appl Biochem Biotechnol 166:146-158

17. Nicol RW, Marchand K, Lubitz WD (2012) Bioconversion of crude glycerol by fungi. Appl Microbiol Biotechnol 93:1865-1875

18. Hou CT (2008) (2008) Production of arachidonic acid and dihomo- $\gamma$-linolenic acid from glycerol by oil-producing filamentous fungi, Mortierella in the ARS culture collection. J Ind Microbiol Biotechnol 35:501-506

19. Dedyukhina EG, Chistyakova TI, Kamzolova SV, Vinter MV, Vainshtein MB (2012) Arachidonic acid synthesis by glycerol-grown Mortierella alpina. Eur J Lipid Sci Technol 114:833-841

20. Dedyukhina EG, Chistyakova TI, Mironov AA, Kamzolova SV, Morgunov IG, Vainshtein MB (2014) Arachidonic acid synthesis from biodiesel-derived waste by Mortierella alpina. Eur J Lipid Sci Technol 116:429-437

21. Economou CN, Makri A, Aggelis G, Pavlou S, Vayenas DV (2010) Semi-solid state fermentation of sweet sorghum for the biotechnological production of single cell oil. Biores Technol 101:1385-1388

22. Economou CN, Aggelis G, Pavlou S, Vayenas DV (2011) Single cell oil production from rice hulls hydrolysate. Biores Technol 102:9737-9742

23. Economou CN, Vasiliadou IA, Aggelis G, Pavlou S, Vayenas DV (2011) Modeling of oleaginous fungal biofilm developed on semi-solid media. Biores Technol 102:9697-9704

24. Economou CN, Aggelis G, Pavlou S, Vayenas DV (2011) Modeling of single-cell oil production under nitrogen limited and substrate inhibition conditions. Biotechnol Bioeng 108:1049-1055

25. Bellou S, Makri A, Sarris D, Michos K, Rentoumi P, Celik A, Papanikolaou S, Aggelis G (2014) The olive mill wastewater as substrate for single cell oil production by Zygomycetes. J Biotechnol 170:50-59

26. Vasyukova NI, Gerasimova NG, Chalenko GI, Ozeretskovskaya OL (2012) Elicitor activity of chitosan and arachidonic acid: Their similarity and distinction. Appl Biochem Microbiol (English translation from Prikl Biokhim Mikrobiol) 48:109-116

27. Bostock RM, Kuc JA, Laine RA (1981) Eicosapentaenoic and arachidonic acids from Phytophthora infestans elicit fungitoxic sesquiterpenes in the potato. Sci 212:67-69

28. Il'inskaya OOL (1998) Fatty acid lipoxygenation products as signal molecules inducing the resistance of plants (Review). Appl Biochem Microbiol (English translation from Prikl Biokhim Mikrobiol) 34:467-479

29. Ozeretskovskaya OL, Il'inskaya LI, Vasyukova NI (1994) Mechanisms of induction of the plant systemic resistance to diseases by elicitors. Plant Physiol (Physiologia rastenii, Moscow, in Russian) 41:626-633

30. Ozeretskovskaya OL (1994) Induction of plant resistance with biogenic elicitors of phytopathogens. Appl Biochem Microbiol (English translation from Prikl Biokhim Mikrobiol) 30:325-339 
31. Preisig C, Kuc JA (1985) Arachidonic acid-related elicitors of the hypersensitive response in potato and enhancement of their activities by glucans from Phytophthora infestans (Mont.) deBary. Archiv Biochem Biophys 236:379-389

32. Preisig CL, Kuc JA (1988) Metabolism by potato tuber of arachidonic acid, an elicitor of hypersensitive resistance. Physiol Mol Plant Pathol 32:77-88

33. Ozeretskovskaya OL, Varlamov VP, Vasyukova NI, Chalenko Gl, Gerasimova NG, Panina YS (2004) Effect of systemic signaling molecules on the rate of spread of the immunizing effect of elicitors over potato tissues. Appl Biochem Microbiol (English translation from Prikl Biokhim Mikrobiol) 40:252-256

34. Metlitskii LV, Ozeretskovskaya OL, Chalova LI, Ivanyuk VG, Chalenko GI, Platonova TA (1985) Immunization of plants with the use of biogenic inductor of systemic defense reactions. Plant Physiology (in Russian) 286:253-256

35. Bostock RM, Yamamoto H, Choi D, Ricker KE, Ward BL (1992) Rapid stimulation of 5 -lipoxygenase activity in potato by the fungal elicitor arachidonic acid. Plant Physiol 100:1448-1456

36. Tjamos EC, Kucacute JA (1982) Inhibition of steroid glycoalkaloid accumulation by arachidonic and eicosapentaenoic acids in potato. Science 217:542-544

37. Choi D, Ward BL, Bostock RM (1992) Differential induction and suppression of potato 3-hydroxy-3-methylglutaryl coenzyme A reductase genes in response to Phytophthora infestans and to its elicitor arachidonic acid. Plant Cell 4:1333-1344

38. Qi B, Fraser T, Mugford S, Dobson G, Sayanova O, Butler J, Napier JA, Stobart AK, Lazarus CM (2004) Production of very long chain polyunsaturated omega-3 and omega-6 fatty acids in plants. Nat Biotechnol 22:739-745

39. Savchenko T, Walley JW, Chehab EW, Xiao Y, Kaspi R, Pye MF, Mohamed ME, Lazarus CM, Bostock RM, Dehesh K (2010) Arachidonic acid: an evolutionarily conserved signaling molecule modulates plant stress signaling networks. Plant Cell 22:3193-3205

40. Vasyukova NI, Chalenko Gl, Gerasimova NG, Valueva TA, Ozeretskovskaya OL (2008) Activation of elicitor defensive properties by systemic signal molecules during the interaction between potato and the late blight agent. Appl Biochem Microbiol (English translation from Prikl Biokhim Mikrobiol) 44:236-240

41. Ivanyuk VG, Chalova LI, Yurganova LA, Ozeretskovskaya OL, Karavaeva KA (1990) Immunization of tomatoes by biogenic inductors of protective reactions. Vestn S-H Nauki (Moscow) no 5:144-146 (in Russian)

42. Eroshin VK, Dedyukhina EG (2002) Effect of lipids from Mortierella hygrophila on plant resistance to phytopathogens. World J Microbiol Biotechnol 18:165-167

43. Ozeretskovskaya OL, Vasyukova NI (2002) The use of elicitors for defense of agricultural plants demands a care. Appl Biochem Microbiol (English translation from Prikl Biokhim Mikrobiol) 38:322-325

\section{doi:10.1186/s40538-014-0018-9}

Cite this article as: Dedyukhina et al:: Arachidonic acid as an elicitor of the plant defense response to phytopathogens. Chemical and Biological Technologies in Agriculture 2014 1:18.

\section{Submit your manuscript to a SpringerOpen ${ }^{\circ}$ journal and benefit from:}

- Convenient online submission

- Rigorous peer review

- Immediate publication on acceptance

- Open access: articles freely available online

- High visibility within the field

- Retaining the copyright to your article

Submit your next manuscript at $\gg$ springeropen.com 